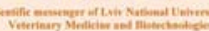
(20) 15

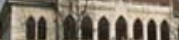

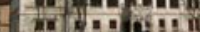
G.9.

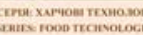

Науковий вісник Дьвівського національного університету ветеринарної медицини та біотехнологій імені С.3. Гжицького. Серія: Харчові технології

\author{
Scientific Messenger of Lviv National University
} of Veterinary Medicine and Biotechnologies.

Series: Food Technologies

ISSN 2519-268X print

https://nvlvet.com.ua/index.php/food

doi: $10.32718 /$ nvlvet-f9106

\title{
Effect of the modified silica on the conductivity and sensory properties of polyaniline nanocomposites
}

\author{
Yu.Yu. Horbenko ${ }^{1}$, B.R. Tsizh ${ }^{2,3}$, O.I. Aksimentyeva ${ }^{1}$, I.B. Olenych ${ }^{1}$, V.M. Bogatyrev ${ }^{4}$, M.R. Dzeryn ${ }^{2}$ \\ ${ }^{I}$ Ivan Franko National University of Lviv, Lviv, Ukraine \\ ${ }^{2}$ Stepan Gzytsky Lviv National University of Veterinary Medicine and Biotechnologies, Lviv, Ukraine \\ ${ }^{3}$ Kazimierz Wielki University in Bydgoszcz, Bydgoszcz, Poland \\ ${ }^{4}$ O.O. Chuiko Institute of Surface Chemistry NAS of Ukraine, Kyiv, Ukraine
}

Article info

Received 15.01.2019

Received in revised form 13.02.2019

Accepted 14.02.2019

Ivan Franko National University of Lviv, Universytetska St., 1 , Lviv, 79000, Ukraine.

Stepan Gzhytskyi National University of Veterinary Medicine and Biotechnologies Lviv, Pekarska Str., 50, Lviv, 79010, Ukraine. Tel.: +38-032-239-26-35 E-mail:tsizhb@ukr.net

Kazimierz Wielki University in Bydgoszcz, Bydgoszcz, 85-064, Poland.

O.O. Chuiko Institute of Surface Chemistry NAS of Ukraine, Henerala Naumova, Str., 17, Kyiv, 03164, Ukraine.
Horbenko, Yu.Yu., Tsizh, B.R., Aksimentyeva, O.I., Olenych, I.B., Bogatyrev, V.M., \& Dzeryn, M.R. (2019). Effect of the modified silica on the conductivity and sensory properties of polyaniline nanocomposites. Scientific Messenger of Lviv National University of Veterinary Medicine and Biotechnologies. Series: Food Technologies, 21(91), 29-37. doi: 10.32718/nvlvet-f9106

The introduction of nanosized fillers into composites with conductive polymers allows them to control physical and chemical characteristics of these polymers. Silica nanoparticles due to its remarkable properties, which include large ratio of surface area to volume, excellent chemical stability, low cost of synthesis, and low toxicity, especially convenient surface modification, have attracted much attention of researchers. Such materials may be as excellent platforms for development of smart sensing systems for numerous applications in analytical chemistry and bioanalysis, in medical diagnostics and therapy, environmental and food analysis, security. It is known that the presence of nanosized silica in the structure of hybrid polymeric composites can not only radically change the structure, but also lead to improved mechanical characteristics, sorption capacity, increase or decrease in specific conductivity. In this work the method of polymerization filling "in situ" was used for preparation of the hybrid composites of polyaniline with nanoparticles of silica modified by titanium (TAC-7) and phosphorus (F-2.1) compounds, studied their morphology, electrical and moisture absorption properties. Influence of the content of inorganic component in composites on their specific conductivity, activation parameters of conductivity and their changes under the action of moisture were studied. It is shown that the filler content of $1-4 \%$ increases the electrical conductivity of composites and the incorporation of modified nanoparticles F-2.1 helps stabilize the resistivity of nanocomposites at high humidity. The resistivity change less than $2 \%$ was observed throughout the whole range of possible moisture, therefore the obtained modified material can be recommended for using in the resistive sensors operating in the condition of high humidity. Moreover, F-2.1 enhances sensitivity of polymer matrix to hydrogen chloride vapors. So, the possibility of using chemically deposited thin films of polyaniline/modified silica nanocomposite for the optical gas sensors production for various purposes, including monitoring the state of environments in real conditions of atmosphere, is shown.

Key words: polyaniline, silica, morphology, nanocomposite, resistivity, moisture absorption, sensory properties.

\section{Вплив модифікованого кремнезему на провідність та сенсорні властивості нанокомпозитів поліаніліну}

\author{
Ю.Ю. Горбенко ${ }^{1}$, Б.Р. Ціж ${ }^{2,3}$, О.І. Аксіментьєва ${ }^{1}$, І.Б. Оленич ${ }^{1}$, В.М. Богатирьов ${ }^{4}$, М.Р. Дзерин ${ }^{2}$ \\ ${ }^{1}$ Львівський національний університет імені Івана Франка, м. Львів, Україна \\ ${ }^{2}$ Львівський національний університет ветеринарної медицини та біотехнологій імені С.3. Гжсицького, \\ м. Львів, Україна \\ ${ }^{3}$ Університет Казимира Великого в Бидгощі, Бидгощ,, Польщุа \\ ${ }^{4}$ Інститут хімї̈ поверхні ім. О.О. Чуйка Національної академії наук Украӥни, м. Київ, Україна
}


Введення нанорозмірних наповнювачів до складу композитів на основі провідних полімерів дозволяє контролювати фізикохімічні характеристики ичих полімерів. Наночастинки кремнезему привертають значну увагу дослідників завдяки чудовим властивостям, що включають велике співвідношення площі поверхні до об'єму, відмінну хімічну стабільність, малу вартість синтезу $і$ токсичність, особливо зручну модифікацію поверхні. Такі матеріали можуть бути відмінною основою для розробки інтелектуальних систем зондування для численних застосувань в аналітичній хімії та біоаналізі, у медичній діагностииі та терапї, екологічному та харчовому аналізі, безпеці. Відомо, щуо наявність нанорозмірного кремнезему в складі гібридних полімерних композитів може не тільки радикально змінити їхню структуру, але і поліпшити механічні характеристики, сорбційну ємність, змінити питому електропровідність. У роботі використаний метод полімеризаційного наповнення “іп sіtи” для отримання гібридних композитів поліаніліну з наночастинками кремнезему, модифікованого сполуками титану (ТАE-7) $і$ фосфору (P-2.1), вивчено їхню морфологію, електричні та водопоглинаючі властивості. Досліджено вплив вмісту неорганічного компонента в композитах на питому електропровідність, активаційні параметри провідності та їхні зміни під дією вологи. Показано, щуо вміст наповнювача 1-4\% збільшує електропровідність композитів, а також інкорпорація модифікованих наночастинок Р-2.1 сприяє стабілізації питомого опору нанокомпозитів при високій вологості. 3міни питомого опору менше 2\% спостерігалися у всьому діапазоні можливої вологості, тому отриманий модифікований матеріал може бути рекомендований для застосування в резистивних сенсорах, щзо працюють в умовах високої вологості. Крім того, Р-2.1 підвищує чутливість полімерної матриці до парів хлороводню. Отжже, показана можливість використання хімічно осаджених тонких плівок нанокомпозиту поліанілін/модифікований кремнезем для виробництва оптичних газових сенсорів для різних иілей, включаючи моніторинг стану середовищ в реальних умовах атмосфери.

Ключові слова: поліанілін, кремнезем, морфологія, нанокомпозит, питомий опір, поглинання вологи, сенсорні властивості.

\section{Introduction}

Semiconductor polymers with a system of conjugated electronic bonds are promising materials for electronic technology, since they exhibit interesting optical properties, the ability to convert light energy, have sensitivity to chemical and physical influences (Tsizh et al., 2016; Naveen et al., 2017; Pavase et al., 2018; Cichosz et al., 2018; Liu et al., 2019).

One of the most important properties of these materials is their ability to change the resistivity in a wide range of values - from insulators to metals. Such changes can be controlled using methods of chemical or electrochemical doping (Awuzie, 2017; Lu et al., 2018). Polyaniline (PAn) is known as one of the most important in the technological layout of conductive polymers, due to its high electrical conductivity, ease of obtaining, atmospheric stability and relatively low cost (ĆirićMarjanović, 2013). This polymer is of great interest because of the possibility of its application in various hitech aspects, for example, in electrochemical displays, sensors, catalysts, capacitors, electromagnetic screens, and also in accumulators (Fratoddi et al., 2015; Wang et al., 2016; Eftekhari et al., 2017; Tanguy et al., 2018; Liao et al., 2019).

The introduction of nanosized fillers into composites with conductive polymers allows them to control the electrical properties of these polymers, their sensitivity and other physical and chemical characteristics (Seo et al., 2017; Konopelnyk et al., 2017; Chethan et al., 2019). With the rapid development of nanotechnology, the silica nanoparticles have attracted much attention of researchers as excellent platforms for development of smart sensing systems for numerous applications in analytical chemistry and bioanalysis, in medical diagnostics and therapy, environmental and food analysis, security (Wang et al., 2008; Ma et al., 2015; Bapat et al., 2016). Silica nanoparticles process a unique set of remarkable properties, which include large ratio of surface area to volume, excellent chemical stability, low cost of synthesis, and low toxicity, especially convenient surface modification (Filonenko et al., 2010; Liberman et al., 2014; Murugadoss et al., 2017).
Most of the known works in the field of obtaining polymer/silica composites are devoted to the use of pyrogenic aerosil - nanoparticles of silicon (IV) oxide as a filler with an unmodified surface ( $\mathrm{Li}$ et al., 2005; Liu, 2008). At the same time, it has been shown that the use of $\mathrm{SiO}_{2}$ nanoparticles modified with metal oxides in hybrid polymer composites can not only change their structure but also improve the mechanical properties (Starokadomskyi et al., 2011). On the other hand, $\mathrm{SiO}_{2}$ and its modifications absorb water very actively, due to the hydrophilic surface functional groups, such as $\mathrm{Si}-\mathrm{OH}$ (Li et al., 2005; Filonenko et al., 2010). Probably the presence of fillers in the composite structure can lead to stabilization of electrical conductivity as a result of binding excess moisture, that eliminate participating of the water molecules in the processes of protonation of emeraldine chloride, respectively, changes of the electrical conductivity.

The choice of gases for studying the sensory properties of hybrid structures is caused by the importance of their control in the atmosphere of residential, office and industrial premises, for the control of food quality (Li et al., 2005; Filonenko et al., 2010; Tsizh et al., 2016; Li et al., 2017). It is known that $\mathrm{HCl}$ is the most commonly used acid in the chemical industry (Misra et al., 2004; Wang et al., 2018). In technological processes the probability of release of hydrogen chloride - a dangerous air pollutant remains. Due to the toxic properties of $\mathrm{HCl}$ in both gaseous and water forms, there is a great need to detect and establish the concentration of these particles. However, currently available $\mathrm{HCl}$ detection methods are long-lasting, complex and expensive. Also, standard sensors, available in the market, operate at high temperatures (Aksimentyeva et al., 2015). Polymer semiconductor electronic sensors offer an attractive alternative due to its potentially low cost, simple packaging, versatility and compatibility with flexible substrates.

So, in this work, the influence of the content of inorganic component in composites on their specific conductivity, activation parameters of conductivity and their changes under the action of moisture were studied. Silica nanoparticles were tested as possible modifier of polymer matrices used in resistive and optical gas sensors 
in real conditions of operation, that is, in an atmosphere with natural humidity.

\section{Materials and research methods}

Hybrid composites of PAn modified with silica nanoparticles were obtained by the method of polymerization filling (Aksimentyeva et al., 2015). Nanoparticles $\mathrm{SiO}_{2}$ (AE, specific surface area $256 \mathrm{~m}^{2} / \mathrm{g}$ ) and its modifications - with titanium (IV) oxide (TAE-7, specific surface area $90 \mathrm{~m}^{2} / \mathrm{g}$ ) and phosphorus (III) chloride (grade P-2.1, specific surface area $124 \mathrm{~m}^{2} / \mathrm{g}$ ), developed at the Chuiko Institute of Surface Chemistry National Academy of Sciences of Ukraine, were used as fillers of the composites. The technology of their production and properties are described in (Zarko et al., 1983; Bogatyrev \& Chuiko, 1984).

Before the synthesis of the composites, $\mathrm{SiO}_{2}$ powder in an amount of $1.4 \mathrm{~g}$ was added to $60 \mathrm{~mL}$ of $1 \mathrm{M} \mathrm{HCl}$ solution and sonicated for $8 \mathrm{~h}$. The resulting colloidal dispersion of silica was added in different proportions into the reaction solution containing aniline (Sigma Aldrich). To the resulting mixture equimolar amount of ammonium persulfate was added dropwise over $4 \mathrm{~h}$ with continuous stirring. Cooling the mixture during synthesis to a temperature $T=-5^{\circ} \mathrm{C}$ was performed in cryostat by liquid nitrogen. PAn without fillers was obtained by oxidative polymerization of aniline in the presence of ammonium persulfate in aqueous solution of hydrochloric acid according to the method described in (Aksimentyeva et al., 2015). The obtained precipitate was filtered, repeatedly washed with distilled water on to completely remove residual electrolyte and dried in a dynamic vacuum at $T=353 \mathrm{~K}$ for $8 \mathrm{~h}$.

Optical microscopy of the samples was performed on microscope "Micromed", to obtain images a digital camera "Nicon-2500" was used. The molecular structure of composites was confirmed by FTIR-spectroscopy with spectrometer "Avatar" for samples pressed into $\mathrm{KBr}$ pellets. The cathode-luminescence was excited by the pulsed flux of electrons with energy up to $E_{\mathrm{p}}=9 \mathrm{keV}$. The frequency of pulses $f=50 \mathrm{~Hz}$, duration $\tau_{\text {imp }}=3$

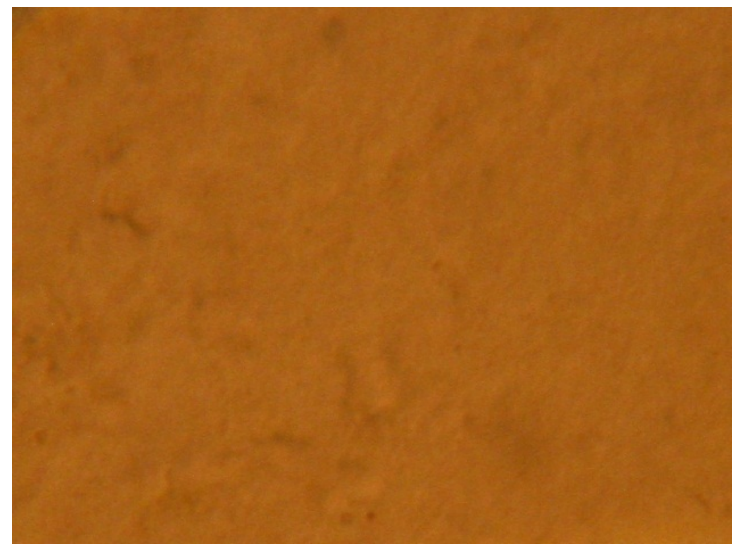

microseconds. The current density in the electron beam reached $j=1500 \mathrm{~A} / \mathrm{m}^{2}$. CL measurements were performed at temperature $78 \mathrm{~K}$. Electrical conductivity of polymer composites was studied in pressed samples by standard 2-contact method at $T=293 \mathrm{~K}$, the temperature dependence of the resistance - according to (Aksimentyeva et al., 2002) in the range $T=293-373 \mathrm{~K}$.

To study the regularities of moisture absorption of samples, it were kept in a sealed chamber with controlled humidity, which was created as the vapor pressure of sulfuric acid solutions of different concentrations (Lurie, 1971). Number of absorbed moisture was determined by gravimetric method. For this purpose weighing of samples were carried before placement in a moist chamber and during exposure at regular intervals. The relative moisture absorption was determined as the ratio of the mass difference to the initial weight of sample.

In order to investigate the sensory properties, thin film elements where obtained by chemical deposition of sensitive layer of PAn and PAn/P-2.1 composite on the optical transparent carrier during the polymerization process according to the method described above. The purified and skimmed glass plate, covered with semiconductor layer $\mathrm{SnO}_{2}$, the size of $10 \times 30 \times 0.5 \mathrm{~mm}$, was kept in the reaction mixture for 10 minutes. After that the resulting polymer films were washed with distilled water and dried in air at room temperature. Obtained samples were kept for a fixed time $(0.5-3 \mathrm{~min})$ in a germetic glass chamber with $\mathrm{HCl}$ vapor.

\section{Results and Discussion}

Formation of hybrid composites of polyaniline with silica was performed using one of the nano-chemical approaches - namely, polymerization filling "in situ", which involves the formation of composite by oxidative polymerization in the presence of nanosize filler in reaction mixture. Ultrasonic processing of silica allowed obtaining a fine dispersion of nanoparticles, during the deposition of which on a solid surface there is formed uniform, dense coating (fig. 1. $a, c$ ).

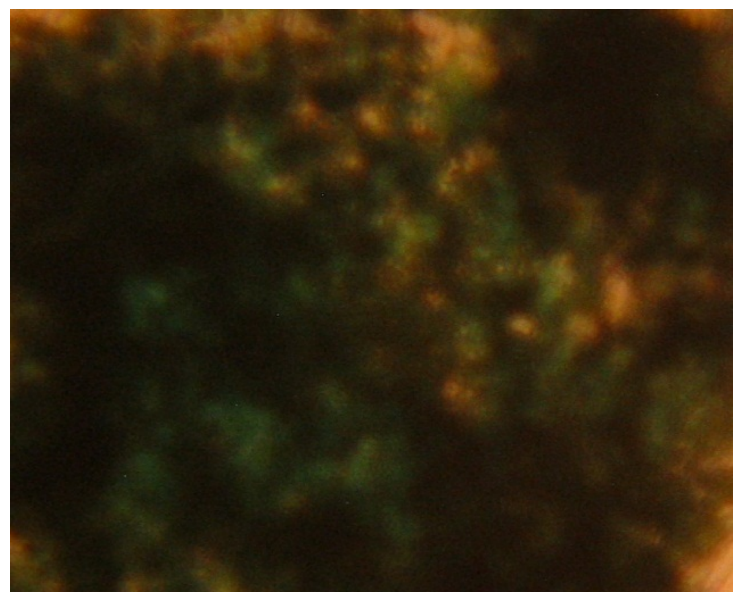

$b$ 


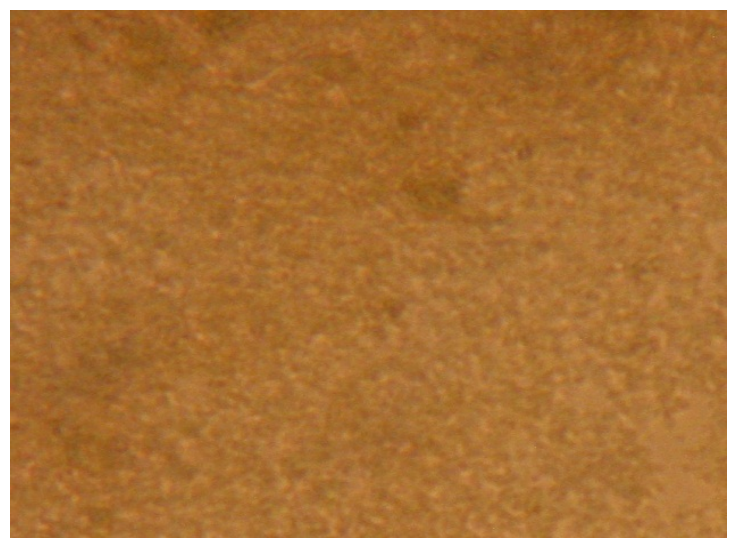

$c$

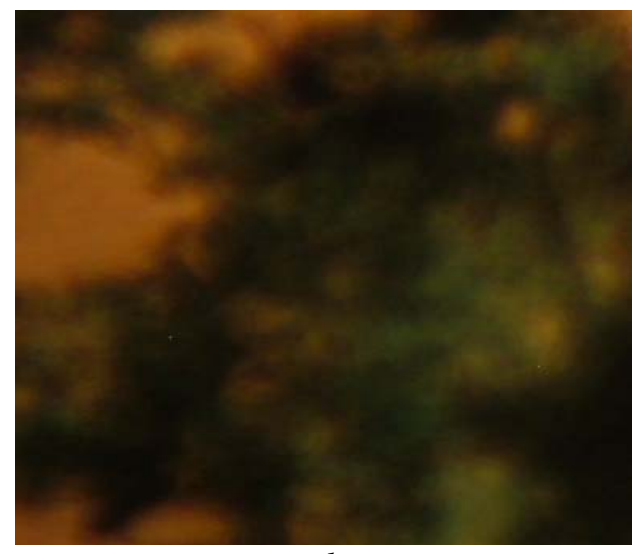

$d$

Fig. 1. Microphotos of colloidal dispersion surface of silica TAE-7 (a) and P-2.1 (c); surface of PAn/TAE-7 (b) and $\mathrm{PAn} / \mathrm{P}-2.1(d)$. The content of silica is $4 \%$ (by weight). Increasing $\times 600$

The obtained photographs show that the morphology of TAE-7 surface has a distinct texture (fig. 1. $a$ ), while in the case of P-2.1 particles preferably have a spherical shape (fig. 1.c). In result of polymerization filling there are formed composite with mainly globular structure, silica particles were surrounded by polymer shell of PAn (fig. 1. $b, d$ ). Bright green color of obtained composites indicates that the polymer is in the form of acid-doped PAn - emeraldine salt of hydrochloric acid.

According FTIR-spectroscopy, the presence of absorption bands at 3400, 3030, 1600, 1480, 1250, 824, $744 \mathrm{~cm}^{-1}$ was established, typical to emeraldine salt (fig. 2). Characteristic peaks at 1460 and $1600 \mathrm{~cm}^{-1}$ can be attributed to linear oscillation of $\mathrm{C}=\mathrm{C}$ bonds of benzoquinoid and quinoid rings respectively. The peak at $1250 \mathrm{~cm}^{-1}$ corresponds to a linear oscillation of C-N bonds of secondary aromatic amines. The bands at 3425 and $3230 \mathrm{~cm}^{-1}$ correspond to N-H and O-H. The peak at $1100 \mathrm{~cm}^{-1}$ is typical for vibrations of Si-O in silica nanoparticles, which are in a good agreement with literature data (Li et al., 2005).

The incorporation of silica nanoparticles into the PAn matrix and differences in the structure of TAE-7 and P2.1 also proves by cathodoluminescence (fig. 3). For the investigated silica, a broad band of emission in the visible region of the spectrum in the range $\lambda=450-650 \mathrm{~nm}$ is characteristic. For P-2.1, emission bands are observed at $\lambda=575$ and $630 \mathrm{~nm}$, while TAE-7 emits almost 6-7 times more intense with one symmetric maximum at $\lambda=$ $510 \mathrm{~nm}$. The incorporation of the silica into the PAn matrix results in the complete suppression of the luminescence of the samples.

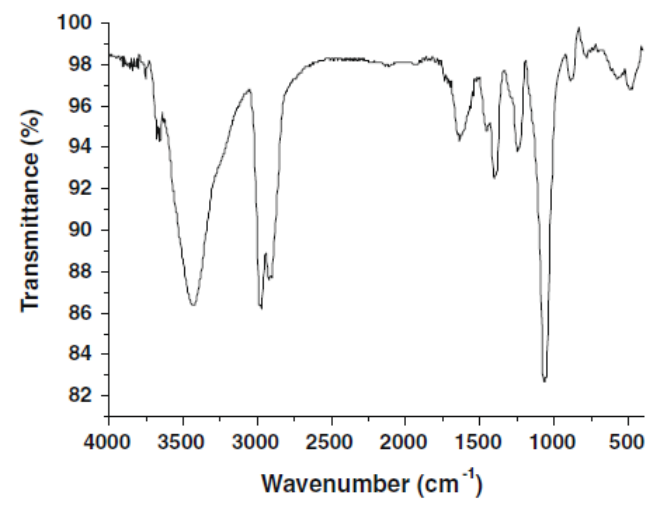

Fig. 2. FTIR spectrum of the PAn/AE hybrid composite (4 wt. \%)

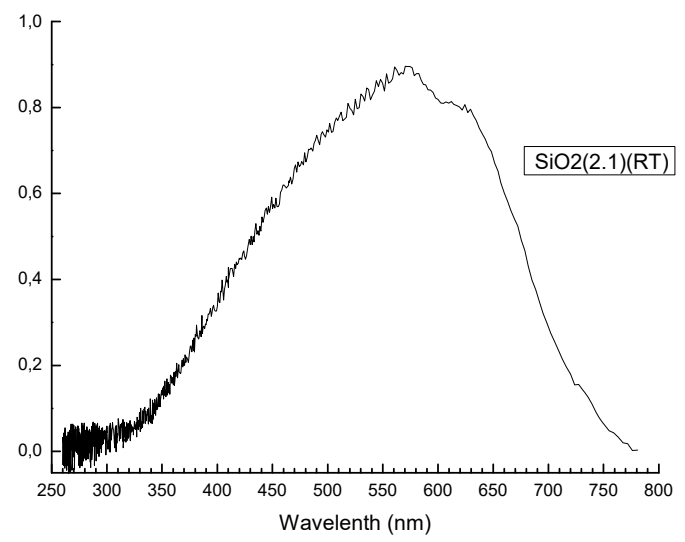

a

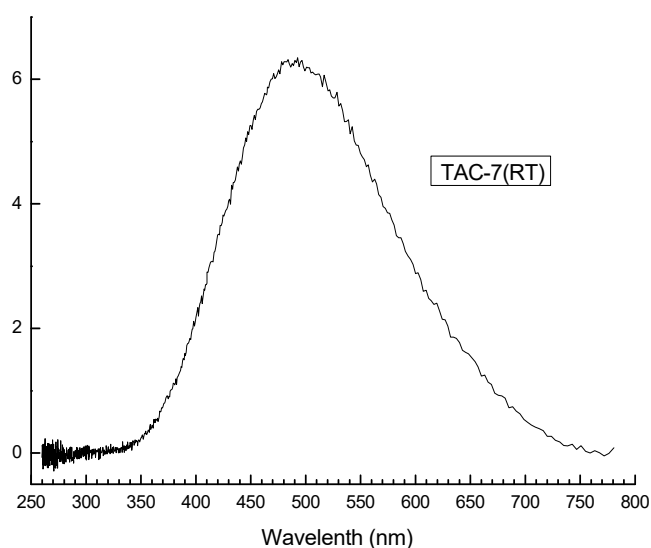

b

Fig. 3. Cadodoluminescence spectra of modified silica TAE-7 (a), P-2.1 (b) at room temperature 
It is known that the presence of nanosized silica in the structure of hybrid polymeric composites can not only radically change the structure, but also lead to improved mechanical characteristics, sorption capacity, increase or decrease in specific conductivity (Li et al., 2005; Pacher et al., 2010).

To study the effect of the filler on the electrical properties of composites there were synthesized samples with different content of colloidal silica. Measurements of resistance of obtained composites at room temperature showed that the content of AE within $0,8-2,4$ wt. \% decreases the resistance of the composite compared with polymer without filler, and in the case of the content of AE within 3,2-4 wt. \% a slight growth of the resistance was observed. At concentrations of filler more than $4 \%$ a sharp increase in resistance was taken place (table 1). In the case of using modified silica as nanosized fillers there are similar concentration dependence. However, reducing the resistivity of composites is carried more noticeable and in the case of the filler content of $4 \%$ resistance falls almost 3.5 times for composite with TAE-7 and 10 times for the composite of P-2.1.

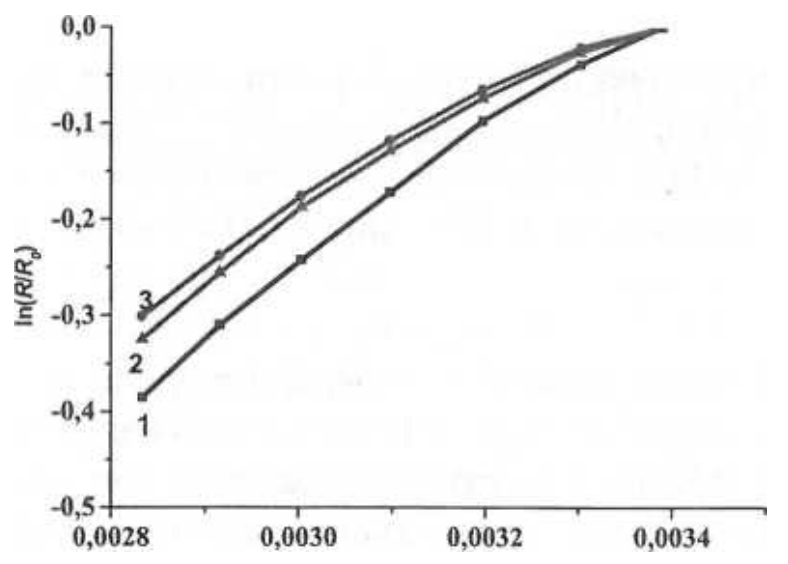

$a$

\section{Table 1}

The influence of the filler on the electrical properties of Pan/silica composites

\begin{tabular}{cccc}
\hline \multirow{2}{*}{$\begin{array}{c}\text { Filler content, } \\
\text { wt. \% }\end{array}$} & \multicolumn{3}{c}{ Resistivity of composite, $T=293 \mathrm{~K}$, Om*m } \\
\cline { 2 - 4 } & PAn/AE & PAn/TAE-7 & PAn/P-2.1 \\
\hline 0 & & $107 \pm 2$ & \\
0.8 & 59 & 40 & 14 \\
2.4 & 25 & 17 & 2 \\
3.2 & 36 & 23 & 6 \\
4 & 42 & 30 & 10 \\
6 & 512 & 483 & 356 \\
10 & $1.5^{*} 10^{6}$ & $9.8^{*} 10^{5}$ & $1.1 * 10^{5}$ \\
\hline
\end{tabular}

The fact of increasing the conductivity of PAN, doped $\mathrm{HCl}$, at the presence of silica may be caused by the formation of nanostructured conductive network in conjugated polymers, due process of structuring of silica colloidal dispersion to form a three-dimensional spatial grid (Goncharuk et al., 2010).

The resulting hybrid composites behave like typical semiconductors - namely, with increasing temperature, their resistance decreases (fig. 4).

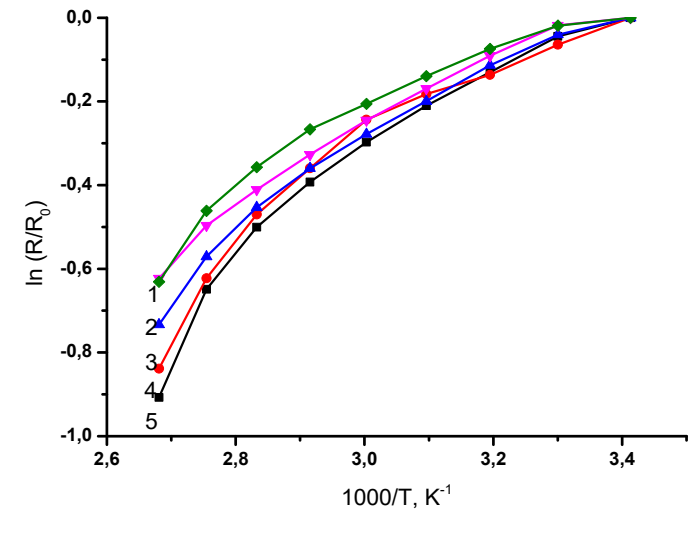

$b$

Fig. 4. (a) The dependencies of the logarithm of the normalized resistance on the inverse temperature of PAn (1), PAn/TAE-7 (2), PAn/P-2.1 (3). The content of filler is 4 wt. \%; (b) Temperature dependence of conductivity of PAn/F-2.1 at different humidity: 75 (1), 56 (2), 35 (3), 17 (4), 0 (5) \%

Presenting this data in coordinates of activation equation $\rho=\rho_{\mathrm{o}} \exp \left(E_{\mathrm{a}} / 2 \mathrm{k} T\right)$ as the dependence of logarithm of the resistivity on the inverse temperature $(1 / \mathrm{T})$ allows to calculate the value of activation energy of charge transfer $\left(E_{\mathrm{a}}\right)$. Due to the calculations, the value of $E_{\mathrm{a}}$ in composites varies in a small extent compared with the PAn. So, the $E_{\mathrm{a}}$ for PAn sample is $0.127 \pm 0.005 \mathrm{eV}$, while for PAn/AE - $0.124 \pm 0.005 \mathrm{eV}$, for PAn/TAE-7 $0.132 \pm 0.005 \mathrm{eV}$ and for PAn/P-2.1 $-0.107 \pm 0.003 \mathrm{eV}$ at $2,4 \%$ loading.

In order to study the effect of silica on charge transport processes in hybrid composites of polyaniline under the influence of moisture, the resistivity of composites and temperature dependence of the resistivity after keeping of samples in cells with different humidity were measured. The general laws of water absorption for all samples exhibit similar features. If environmental humidity is near atmospheric $(\psi=56 \%)$, mass of the samples almost unchanged (fig. 5). At lower values of $\psi$ decrease the mass of the samples is observed, while at higher values - significant increment. Depending on the content of samples the intensity of moisture sorptiondesorption processes varies. In the case of standing in dry atmosphere $(\psi=2 \%)$ the weight decrease of samples were observed due to desorption of water. Samples modified with silica show elevated moisture content (16$21 \%$ ) compared to the unmodified PAn (14\%). At high humidity a polymer matrix possesses the greatest ability for water absorption (to 186\%) and the samples of Pan/P2.1 - the least $(73 \%)$. 


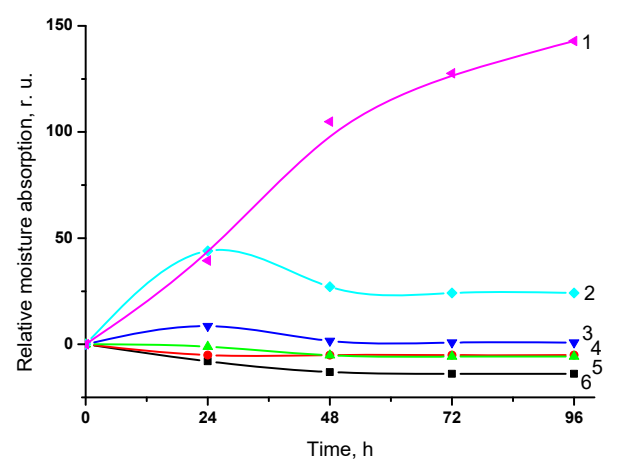

$a$

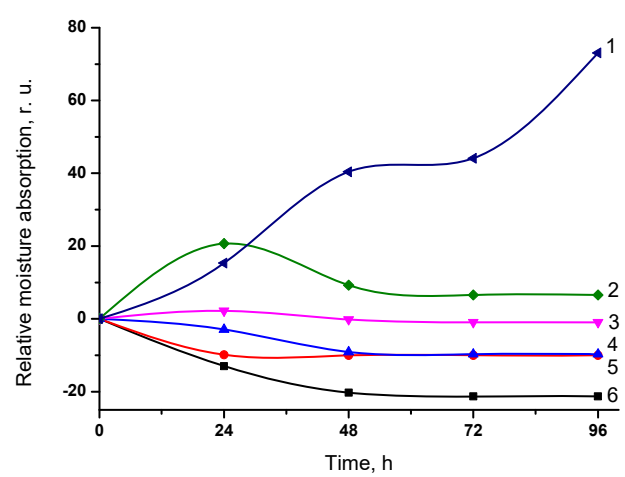

$b$

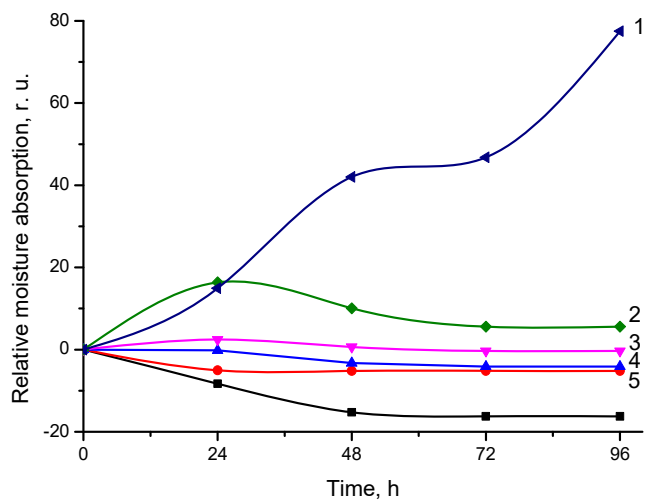

$c$

Fig. 5. Relative water absorption of samples PAn (a), PAn/P-2.1 (b), PAn/TAE-7 (c) at different humidity: $100(1), 75$ (2), 56 (3), 35 (4), 17 (5), 2 (6) \%

\section{Table 2}

Parameters of conductivity of polyaniline-silica composite (4 wt. \%) under the 96 -hour endurance of samples in the atmosphere with different relative humidity $\Psi, \%$

\begin{tabular}{|c|c|c|c|}
\hline \multirow{2}{*}{$\begin{array}{l}\text { Humidity, } \\
\Psi, \%\end{array}$} & \multicolumn{3}{|c|}{$\begin{array}{l}\text { Resistivity, } \rho_{293}, O m * m \text { (The activation } \\
\left.\text { energy of conductivity, } E_{\mathrm{a}}, \mathrm{eV}\right)\end{array}$} \\
\hline & PAn & PAn/TAE-7 & PAn/F2.1 \\
\hline 100 & $\begin{array}{l}270 \\
(0.21)\end{array}$ & $\begin{array}{c}88 \\
(0.14)\end{array}$ & $\begin{array}{c}9,6 \\
(0.11)\end{array}$ \\
\hline 75 & $\begin{array}{c}18 \\
(0.11)\end{array}$ & $\begin{array}{c}73 \\
(0.17)\end{array}$ & $\begin{array}{l}9.8 \\
(0.18)\end{array}$ \\
\hline 56 & $\begin{array}{c}5 \\
(0.15)\end{array}$ & $\begin{array}{c}1.6 \\
(0.12)\end{array}$ & $\begin{array}{c}9.6 \\
(0.12)\end{array}$ \\
\hline 35 & $\begin{array}{l}7.6 \\
(0.10)\end{array}$ & $\begin{array}{c}1.4 \\
(0.11)\end{array}$ & $\begin{array}{c}9.7 \\
(0.14)\end{array}$ \\
\hline 17 & $\begin{array}{c}5,5 \\
(0.12)\end{array}$ & $\begin{array}{c}1.2 \\
(0.13)\end{array}$ & $\begin{array}{c}9.2 \\
(0.14)\end{array}$ \\
\hline 2 & $\begin{array}{c}7.8 \\
(0.12)\end{array}$ & $\begin{array}{c}13 \\
(0.10)\end{array}$ & $\begin{array}{c}9.8 \\
(0.10)\end{array}$ \\
\hline
\end{tabular}

Measurement of conductivity and temperature dependencies of the resistance of composites kept in environments with varying humidity were performed in the range 293-373 K for both samples of the polymer matrix PAn and its composites with silica. As can be seen from table 2, the presence of silica particles leads to a stable value of the resistivity of composites in environments with high humidity versus PAn. The most significant increase of moisture stability of samples is observed in the case of using P-2.1. Throughout the possible range of humidity $(2-100 \%)$ values of resistivity of samples stored at $9.6 \pm 0.2 \mathrm{Ohm}^{*} \mathrm{~m}$, its change does not exceed $\pm 2 \%$, which allow to recommend obtained modified material for use in resistive sensors.

To study the sensory properties of the PAn/P-2.1 hybrid structures, thin-film elements were prepared by chemical precipitation of a sensitive PAn and PAn/P-2.1 layer on an optically transparent substrate (with a $\mathrm{SnO}_{2}$ layer). Comparison of optical spectra of constructed structures is shown in fig. 6 .

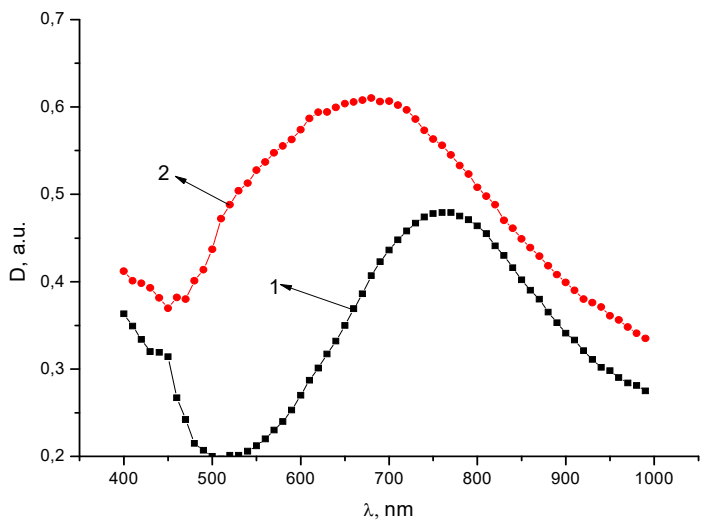

Fig. 6. Optical absorption spectra of PAn (1) and PAn/P-2.1 (2) films 
For samples of polymer, an intensive absorption band with a maximum at $\lambda=760-770 \mathrm{~nm}$ is observed, that is characteristic of acid-doped polyaniline (Tsizh et al., 2016). The absorption spectrum of the modified sample differs considerably, namely, the width of the band increases significantly, and the position of the absorption maximum moves toward the smaller wavelengths, $\lambda=680 \mathrm{~nm}$. This spectrum is typical for PAn, which has a large number of reduced amino-quinoid fragments, and the band itself is a superposition of optical absorption of PAn with varying degrees of oxidation-reduction (Tsizh et al., 2016).

It has been established that the influence of $\mathrm{HCl}$ vapours on the optical spectrum of unmodified PAn is

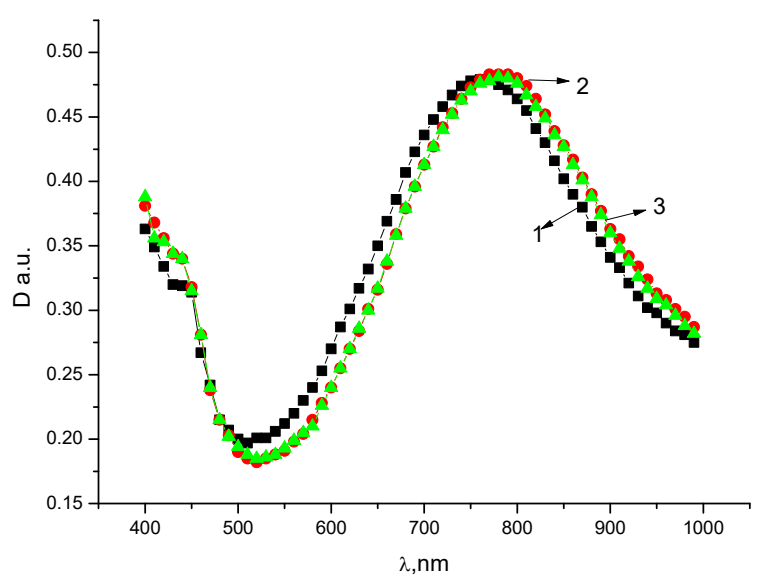

$a$

Fig. 7. Optical absorption spectra of 1 - PAn (a), PAn/P-2.1 (b)

Possible cause of PAn/P-2.1 high sensitivity may be several factors. One of them consist in increasing of the contact area of the sensing medium with the analyte, and, accordingly, to adsorb ability, due to the inclusion of nanodispersed particles in the polymer matrix. The second one consist in the properties of surface of the modifier, namely, P-2.1. It should be expected existence of the centers with basic properties on the silica surface, such as hydroxyl and amino groups, as well as phosphine residues. The ability of surface functional groups to form chemical bonds with the $\mathrm{HCl}$ molecules, in particular saline forms, causes a change in the optical absorption of PAn/P-2.1 samples.

\section{Conclusions}

It is shown that the silica content of $1-4 \%$ causes an increasing of composite conductivity, more over the introduction of silica contributes to the stabilization of the polyaniline resistance at high humidity $(\psi>70 \%)$.

The presence of silica particles leads to a significant increase of moisture stability of the samples, the most significant was observed when using silica brand F-2.1. The resistivity change less than $2 \%$ was observed throughout the whole range of possible moisture, insignificant (fig. 7,a), since the polymer is in the form of emeraldinium chloride with an equilibrium degree of doping and all available for interactions with hydrogen chloride amino groups are busy. A completely different behavior is observed for PAn/P-2.1 films (fig. 7,b). As the sample exposure time increases in the atmosphere of the gaseous $\mathrm{HCl}$, the shift of the absorption maximum toward the larger wavelengths, $\Delta \lambda=120 \mathrm{~nm}$, and the intensity increasing of this maximum $\Delta D=0.081(11.7 \%)$ are observed. In addition, significant changes can be traced after $30 \mathrm{~s}$ of $\mathrm{HCl}$ vapor influence.

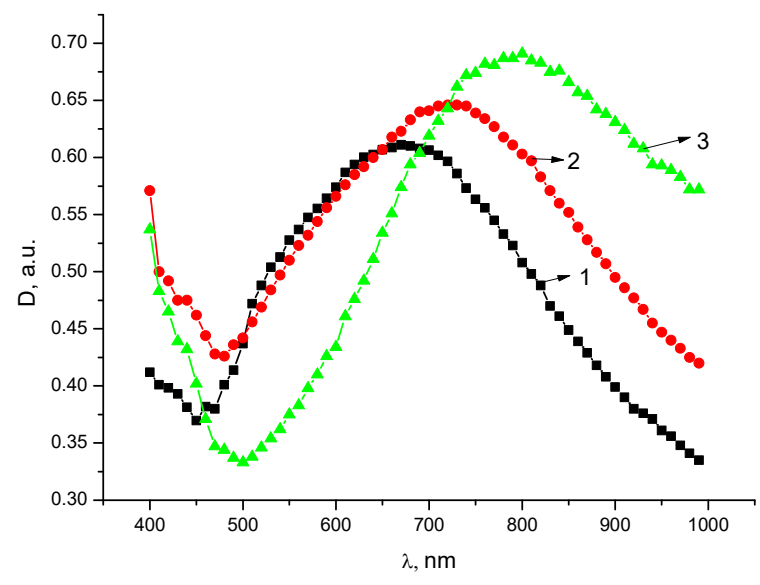

$b$

(b) films under $\mathrm{HCl}$ vapor influence during $2-30,3-180 \mathrm{~s}$

therefore the obtained modified material can be recommended for using in the resistive sensors operating in the condition of high humidity.

So, in this work, the influence of the content of inorganic component in composites on their specific conductivity, activation parameters of conductivity and their changes under the action of moisture were studied. It has been established that introduction of modified silica nanoparticles F-2.1 into the polyaniline matrix caused enhanced sensitivity of composites to $\mathrm{HCl}$ vapors. This effect can be used for development of gas sensors.

\section{Prospects for further research}

Based on the obtained data, the possibility of using chemically deposited thin films of polyaniline/modified silica nanocomposite for the gas sensors production for various purposes, including controlling the food freshness and monitoring the state of environments in real conditions of atmosphere, is shown. The next stage of research will be improving of sensory properties by optimization of synthesis conditions of hybrid composites, as well as studying their sensory sensitivity to other gases (hydrogen sulfide, nitrogen oxides etc.). 
This work was supported by the project of Ministry of Education and Science of Ukraine "Development of organo-inorganic thin film reversible structures for multifunctional gas sensors" (state registration number 0118u003496).

\section{References}

Aksimentyeva, O.I., Grytsiv, M.Y., \& Konopelnyk, O.I. (2002). Temperature dependence of resistance and thermal stability of doped polyaniline. Functional Materials, 9(2), 251-254.

Aksimentyeva, O.I., Bogatyrev, V.M., Martynyuk, G.V., Olenych, I.B., Horbenko, Yu., \& Kit, L. (2015). Synthesis and electrical properties of composites of polyaniline with silica. Scientific notes of Ternopil National Pedagogical University named after Vladimir Gnatyuk. Series: Chemistry, 22, 11-14 (in Ukrainian).

Awuzie, C.I. (2017). Conducting Polymers. Materials today: Proceedings, 4(4-E), 5721-5726. doi: 10.1016/j.matpr.2017.06.036.

Bapat, G., Labade, C., Chaudhari, A., \& Zinjarde, S. (2016). Silica nanoparticle based techniques for extraction, detection, and degradation of pesticides. Advances in Colloid and Interface Science, 237, 1-14. doi: 10.1016/j.cis.2016.06.001.

Bogatyrev, V.M., \& Chuiko, A.A. (1984). Interaction of phosphorus trichloride with dehydrated aerosil on its surface. Ukrainian Chemical Journal, 50(8), 831-835 (in Russian).

Chethan, B., Raj Prakash, H.G., Ravikiran, Y.T., Vijayakumari, S.C., Ramana, CH. V.V., Thomas, S., \& Daewon, K. (2019). Enhancing humidity sensing performance of polyaniline/water soluble graphene oxide composite. Talanta, 196, 337-344. doi: 10.1016/j.talanta.2018.12.072.

Cichosz, S., Masek, A., \& Zaborski, M. (2018). Polymerbased sensors: A review. Polymer Testing, 67, 342 348. doi: 10.1016/j.polymertesting.2018.03.024.

Ćirić-Marjanović, G. (2013). Recent advances in polyaniline research: Polymerization mechanisms, structural aspects, properties and applications. Synthetic Metals, 177, 1-47. doi: 10.1016/j.synthmet.2013.06.004.

Eftekhari, A., Li, L., \& Yang, Y. (2017). Polyaniline supercapacitors. Journal of Power Sources, 347, 86107. doi: 10.1016/j.jpowsour.2017.02.054.

Filonenko, O.V., \& Lobanov, V.V. (2010). Ctruktura ta vlastyvosti nanoklasteriv kremnezemu (Ohliad) [Structure and properties of silica nanoclusters (Review)]. Physics and chemistry of solid state, 11(1), 138-149 (in Ukrainian).

Fratoddi, I., Venditti, I., Cametti, C., \& Russo, M.V. (2015). Chemiresistive polyaniline-based gas sensors: A mini review. Sensors and Actuators B: Chemical, 220, 534-548. doi: 10.1016/j.snb.2015.05.107.

Goncharuk, O.B., Malysheva, M.L., Zarko, V.I., \& Grycenko, V.F. (2010). Structuring in dispersions of pyrogenic silica in the presence of non-indifferent electrolytes. Nanoparticles, Nanoclusters, Zerodimension Subjects, 1, 16-23 (in Ukrainian).
Konopelnyk, O.I., Aksimentyeva, O.I., \& Horbenko, Y.Y. (2017). Temperature dependence of conductivity in conjugated polymers doped by carbon nanotubes. Journal of Nano- and Electronic Physics, 9(5), 05011. doi: 10.21272/jnep.9(5).05011.

Li, X., Li, X., Li, Z., Wang, J., \& Zhang, J. (2017). WS2 nanoflakes based selective ammonia sensors at room temperature. Sens. Actuators B Chem., 240, 273-277. doi: 10.1016/j.snb.2016.08.163.

Li, X., Wang G., \& Lib, X. (2005). Surface modification of nano-SiO2 particles using polyaniline. Surf. Coat. Technol., 197, 56-60. doi: 10.1016/j.surfcoat.2004.11.021.

Liao, G., Li, Q., \& Xu, Z. (2019). The chemical modification of polyaniline with enhanced properties: A review. Progress in Organic Coatings, 126, 35-43. doi: 10.1016/j.porgcoat.2018.10.018.

Liberman, A., Mendez, N., Trogler, W.C., \& Kummel, A.C. (2014). Synthesis and surface functionalization of silica nanoparticles for nanomedicine. Surf. Sci. Rep., 69, 132-158. doi: 10.1016/j.surfrep.2014.07.001.

Liu, F., Wang, H., Zhang, Y., Wang, X., \& Zhang, S. (2019). Synthesis of low band-gap 2D conjugated polymers and their application for organic field effect transistors and solar cells. Organic Electronics, 64, 27-36. doi: 10.1016/j.orgel.2018.09.03.

Liu, P. (2008). Preparation and characterization of conducting polyaniline/silica nanosheet composites. Cur. Op. Sol. St. Mater. Sci, 12, 9-13. doi: 10.3329/bjsir.v47i3.13055.

Lu, N., Li, L., Geng, D., \& Liu, M. (2018). A review for polaron dependent charge transport in organic semiconductor. Organic Electronics, 61, 223-234. doi: 10.1016/j.orgel.2018.05.053.

Lurie, Y.Y. (1971). Handbook of Analytical Chemistry. 4th ed. Moscow: Chemistry (in Russian).

Ma, Q., Li, Y., \& Su, X. (2015). Silica nanobead-based sensors for analytical and bioanalytical applications. Trends in Analytical Chemistry, 74, 130-145. doi: 10.1016/j.trac.2015.06.006.

Misra, S.C.K., Mathur, P., Yadav, M., Tiwari, M.K., Garg, S.C., \& Tripathi, P. (2004). Preparation and characterization of vacuum deposited semiconducting nanocrystalline polymeric thin film sensors for detection of HCl. Polymer, 45, 8623-8628. doi: 10.1016/j.polymer.2004.10.010.

Murugadoss, S., Lison, D., Godderis, L., Van Den Brule, S., Mast, J., Brassinne, F., Sebaihi, N., \& Hoet, P.H. (2017). Toxicology of silica nanoparticles: an update. Arch. Toxicol., 91, 2967-3010. doi: 10.1007/s00204017-1993-y.

Naveen, M.H., Gurudatt, N.G., \& Shim, Y.-B. (2017). Applications of conducting polymer composites to electrochemical sensors: A review. Applied materials today, 9, 419-433. doi: 10.1016/j.apmt.2017.09.001.

Pacher, P., Lex, A., Eder, S., Trimmel, G., Slugove, C., List, E.J.W., \& Zojer, E. (2010). A novel concept for humidity compensated sub-ppm ammonia detection. Sensors and Actuators B, 145(1), 181-184. doi: 10.1016/j.snb.2009.11.049.

Pavase, T.R., Lin, H., Shaikh, Q.-U.-U., Hussain, S., Li, Z., Ahmed, I., Lv, L., Sun, L., Shah, S.B.H., \& Kalhoro, 
M.T. (2018). Recent advances of conjugated polymer (CP) nanocomposite-based chemical sensors and their applications in food spoilage detection: A comprehensive review. Sensors and Actuators B: Chemical, 273, 11131138. doi: 10.1016/j.snb.2018.06.118.

Seo, C.U., Yoon, Y., Kim, D.H., Choi, S.Y., Park, W.K., Yoo, J.S., Baek, B., Kwon, S.B., Yang, C.-M., Song, Y.H., Yoon, D.H., Yang, W.S., \& Kim, S. (2018). Fabrication of polyaniline-carbon nano composite for application in sensitive flexible acid sensor. Journal of Industrial and Engineering Chemistry, 64, 97-101. doi: 10.1016/j.jiec.2018.03.031.

Starokadomskyi, D. L., Holovan, S. V., Teleheev, Y. H., Tkachenko, A.A., \& Myschanchuk, B.H. (2011) Dyspersnost kremnezema y modyfytsyrovanye eho poverkhnosty kak faktory usylenyia epoksypolymernoho kompozyta [Dispersion of silica and modification of its surface as factors of strengthening of epoxypolymer composite]. Polymer journ., 33(2), 140-148 (in Russian).

Tanguy, N.R., Thompson, M., \& Yan, N. (2018). A review on advances in application of polyaniline for ammonia detection. Sensors and Actuators B: Chemical, 257, 1044-1064. doi: 10.1016/j.snb.2017.11.008.

Tsizh, B.R., Aksimentyeva, O.I., Olhova, M.R., \& Horbenko, Yu.Yu. (2016). Sensory properties of polyaniline films, obtained on the optically transparent carriers. Scientific Messenger LNUVMBT named after S.Z. Gzhytskyj, 2(68), 121-125 (in Ukrainian).

Tsizh, B., \& Aksimentyeva, O. (2016). Organic highsensitive elements of gas sensors based on conducting polymer films. Molecular Crystals and Liquid Crystals, 639(1), 33-38. doi: 10.1080/15421406.2016.1254490.

Wang, H., Lin, J., \& Shen, Z.X. (2016) Polyaniline (PANi) based electrode materials for energy storage and conversion. Journal of Science: Advanced Materials and Devices, 1(3), 225-255. doi: 10.1016/j.jsamd.2016.08.001.

Wang, J., Li, Zh., Zhang, S., Yan, Sh., Cao, B., Wang, Zh., \& Fu, Y. (2018). Enhanced NH3 gas-sensing performance of silica modified $\mathrm{CeO} 2$ nanostructure based sensors. Sensors and Actuators B, 255, 862870. doi: 10.1016/j.snb.2017.08.149.

Wang, L., Zhao, W., \& Tan, W. (2008). Bioconjugated silica nanoparticles: development and applications. Nano. Res., 1, 99-115. doi: 10.1007/s12274-0088018-3.

Zarko, V.I., Goethe, V., Kozub, G.M., \& Chuiko, A.A. (1983). Structural and electrical properties of titaniumcontaining silica. News of the USSR Academy of Sciences. Inorganic materials, 19(2), 239-241 (in Russian). 